\title{
Therapeutic advances in hormone-dependent cancers: focus on prostate, breast and ovarian cancers
}

\author{
Michael UIm ${ }^{1,2, *}$, Arvind V Ramesh ${ }^{3, *}$, Keely M McNamara4,*, Suriyan Ponnusamy ${ }^{1}$, Hironobu Sasano ${ }^{4}$ and \\ Ramesh Narayanan ${ }^{1,2}$ \\ ${ }^{1}$ University of Tennessee Health Science Center, Memphis, Tennessee, USA \\ ${ }^{2}$ West Cancer Center, Memphis, Tennessee, USA \\ ${ }^{3}$ White Station High School, Memphis, Tennessee, USA \\ ${ }^{4}$ Tohoku University, Miyagi, Japan \\ Correspondence should be addressed to R Narayanan: rnaraya4@uthsc.edu \\ *(M Ulm, A V Ramesh and K M McNamara contributed equally to this work)
}

\begin{abstract}
Hormonal cancers affect over 400,000 men and women and contribute collectively to over 100,000 deaths in the United States alone. Thanks to advances in the understanding of these cancers at the molecular level and to the discovery of several disease-modifying therapeutics, the last decade has seen a plateauing or even a decreasing trend in the number of deaths from these cancers. These advanced therapeutics not only effectively slow the growth of hormonal cancers, but also provide an insight on how these cancers become refractory and evolve as an altogether distinct subset. This review summarizes the current therapeutic trends in hormonal cancers, with focus on prostate, breast and ovarian cancers. The review discusses the clinical drugs being used now, promising molecules that are going through various stages of development and makes some predictions on how the therapeutic landscape will shift in the next decade.
\end{abstract}

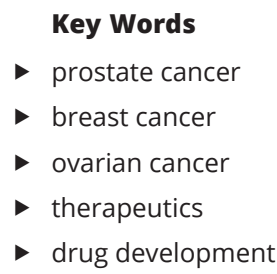

Endocrine Connections (2019) 8, R10-R26

\section{Introduction}

As a class, hormone-dependent cancers, including cancers of the breast, prostate and ovaries, contribute to the majority of cancer incidences in the United States and around the world. Over 400,000 men and women were affected by hormonal cancers and over 100,000 deaths occured in 2018 in the United States alone. Improvements in the understanding of these cancers at the molecular level have contributed to their better management over the last decade. Since 2010, the number of therapeutics to treat these cancers has substantially increased. These new treatment options, though extended the progressionfree and overall survival, have also contributed to more resistant and aggressive disease variants. For example, although undisputedly the second-generation treatments for prostate cancer such as enzalutamide and abiraterone have extended the survival of the patients, the cancers that relapse from these treatments have a more aggressive phenotype. This review on the therapeutic advances of hormone-dependent cancers focuses on three therapeutically challenging and scientifically fascinating cancers, viz. prostate, breast and ovarian cancers.

These three cancers share several similarities and hence have been combined in this review. Prostate and hormone receptor-positive breast cancers share the common feature of their dependence on the respective male and female hormones for their continued growth. Both estrogen receptor (ER) and androgen receptor (AR) are promoters of growth of these two cancers. However, lack of these two receptors results in a less differentiated phenotype, an increase in the proliferative rate, and become 
unresponsive to any treatments, resulting in shorter overall survival. On the other hand, breast and ovarian cancers share the common feature of high rate of BRCA mutations and DNA damage and respond to common treatment modalities such as ER antagonists, PARPi and mTOR inhibitors, indicating the activation of common pathways and that they share a common histological phenotype. Additionally, Cluster of Orthologous Groups studies (COGS) identified 18 regions spanning $2 \mathrm{MB}$ loci which were associated with more than one of the three cancers. Two of the regions contained risk loci for all three cancers (5p15.11 and 8q24.21).

\section{Prostate cancer}

\section{Background}

Prostate cancer (PCa) is the second leading cause of cancer-related deaths in Western men, after lung cancer (1). In 2018, approximately 165,000 men were diagnosed with PCa and 30,000 men died of PCa in the United States (1). PCa incidences are also rising in the world with over a million men being diagnosed with PCa each year and over 300,000 dying from the disease worldwide (2).

\section{Prostate cancer}

The male hormone, androgen that is responsible for the development and maintenance of the prostate gland, is also responsible for the development of PCa. There are multiple stages of PCa progression; each stage is determined based on the severity of the disease, castration or non-castration and metastasis (3). In addition to the stages, PCa is also classified based on the expression of the most important therapeutic target, the AR and based on Gleason score (4). Approximately, $80 \%$ of PCa cases are confined to the organ at the time of diagnosis, while $20 \%$ have metastasized locally or to distant organs. The 5-year survival of local disease is
$100 \%$, while that of the metastasized disease is about $30 \%(5)$.

Numerous therapies are being used to treat $\mathrm{PCa}$, such as androgen-deprivation therapy (ADT) and radiation therapy, but once PCa becomes resistant to any treatment, it will transform into castration-resistant prostate cancer (CRPC); this is the point at which no treatment is completely effective (6). The sequence of treatments provided to PCa patients is summarized in Fig. 1. Many AR-related and non-AR-related pathways help the progression of CRPC, and mechanisms accounting for the emergence of CRPC are summarized in Fig. 2. Although $\mathrm{AR}$ is considered as a promoter of PCa growth, subtypes of $\mathrm{PCa}$, such as neuroendocrine tumors that do not express $\mathrm{AR}$, are extremely aggressive and shorten the survival of patients (7). Such neuroendocrine tumors have to be treated with chemotherapy.

\section{AR signaling as therapeutic target for $\mathrm{PCa}$}

AR is a member of the steroid hormone receptor superfamily of ligand-activated transcription factors. As AR is expressed in more than $90 \%$ of the $\mathrm{PCa}$, it is considered the primary therapeutic target. Since the discovery by Huggins and Hodges in 1940s that PCa is an androgen-dependent disease, AR and androgen-synthesizing enzymes have been the mainstay of PCa therapeutics (8). The various AR-targeted therapeutics currently used in the clinic include luteinizing hormone-releasing hormone (LHRH) agonists or antagonists, $5 \alpha$-reductase inhibitors, AR antagonists and androgen-synthesizing enzyme Cyp17A1 inhibitor (9). PCas that escape from these treatment options will be treated with chemotherapeutic agents such as cabazitaxel or docetaxel (10).

\section{LHRH agonists or antagonists}

LHRH is a major target for ADT therapy. The hypothalamuspituitary-hypogonadal (HPG) axis is important for

\section{PSA}

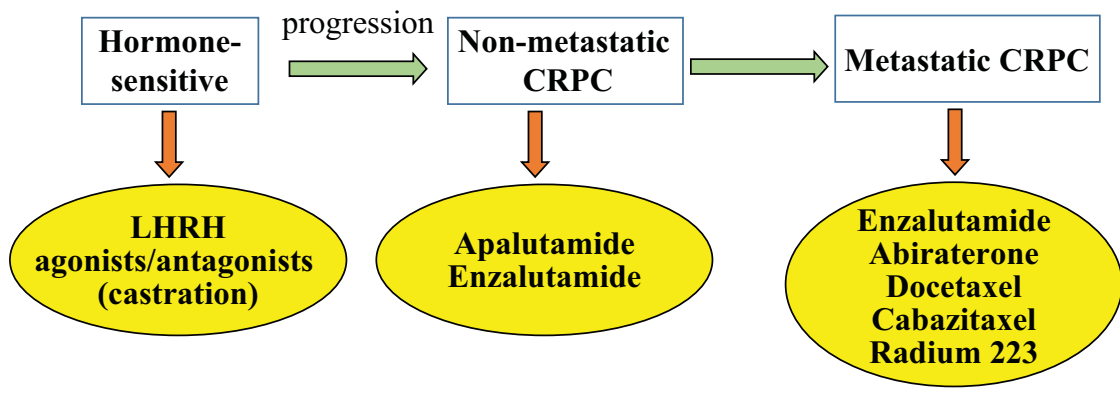

Figure 1

Sequence of treatment at various stages of prostate cancer https://ec.bioscientifica.com https://doi.org/10.1530/EC-18-0425 (c) 2019 The authors Published by Bioscientifica Ltd

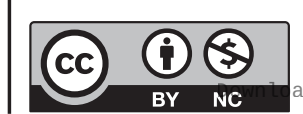

This work is licensed under a Creative Commons Attribution-NonCommercial 4.0 International License. ded from Bioscientifica.com at 04/26/2023 01:48:15PM via free access 


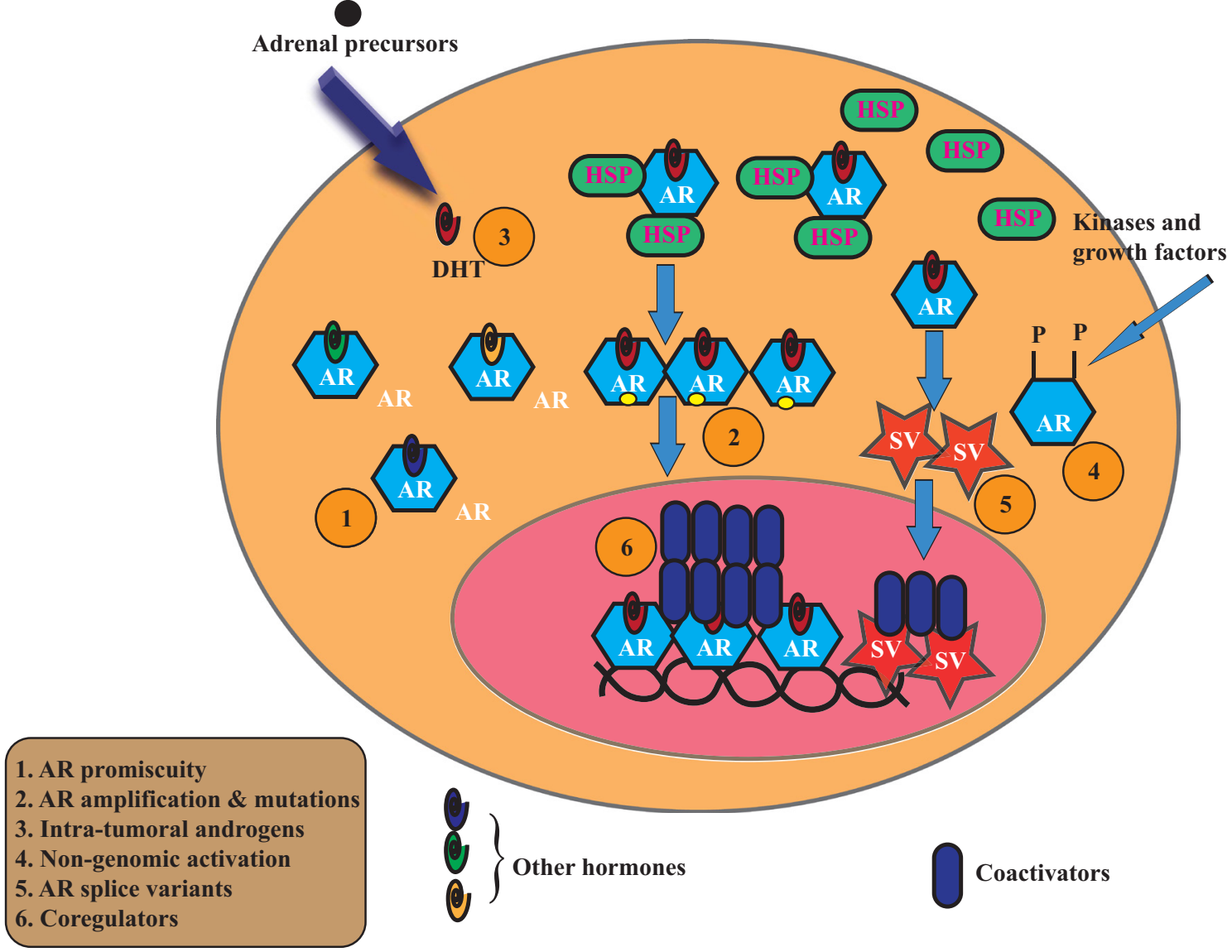

\section{Figure 2}

Mechanisms for castration-resistant prostate cancer (CRPC) emergence. 1. Androgen receptor (AR) promiscuity. Mutations in the AR ligand-binding domain (LBD) will result in the AR being activated by other hormones such as progesterone, corticosteroids, estradiol and others. 2. AR amplification and mutations. The AR copy numbers increase leading to an increase in the expression of AR that will become hyperactive and will respond to low levels of androgens. In addition, mutations in the AR LBD will cause the AR to be refractory to existing treatments. 3. Intra-tumoral androgen synthesis. Androgens such as androstenedione, and DHEA synthesized by the adrenals will be converted locally in the prostate to DHT that will lead to an increase in prostate cancer cell growth. 4. Non-genomic activation. AR can be activated by growth factors and kinases ligand independently, which will cause an increase in the cancer growth. 5. AR splice variants (AR-SVs). CRPCs that have relapsed from existing treatments express AR-SVs. As AR-SVs lack LBD, they are constitutively active and fail to respond to LBD-targeted treatments. 6. Coregulators. AR activity depends on the expression of coactivators. Several studies have indicated that advanced CRPCs have increased expression of coactivators causing the AR to be activated in the presence of castration-level androgens.

the synthesis of testosterone by the testes (11). The hypothalamus releases gonadotropin-releasing hormone (GnRH or LHRH) that stimulates the hypothalamus to secrete luteinizing hormone (LH) and follicle-stimulating hormone (FSH). Increase in LH production is the signal to synthesize testosterone by the testes. Testosterone inhibits the LH secretion through a negative feedback mechanism (12). This feedforward and feedback axis is important to maintain a steady-state level of testosterone. Since this axis plays a pivotal role in the synthesis of testosterone, the main circulating ligand for $\mathrm{AR}$, it serves as an important target for the treatment of PCa.

A LHRH agonist, leuprolide or leuprorelin, binds to GnRH and creates a negative feedback inhibition of the axis, thereby reducing the LH secretion and subsequently testosterone production (13). On the other hand, a LHRH antagonist such as degarelix binds to the GnRH receptor and inhibits its interaction with GnRH and its stimulation of the LH secretion (14). Both leuprolide (approved in 1985) and degarelix (approved in 2008) are administered as injections and considering that PCa requires a longterm treatment, the route of administration is an inconvenience to patients.

\section{$5 \alpha$-reductase inhibitors}

Although LHRH targeting agents work for a short period of time, the cancer escapes by synthesizing DHT intra-tumorally from adrenal precursors such as androstenedione and androstenediol by the enzyme 
$5 \alpha$-reductase (15). Finasteride and dutasteride are the two approved $5 \alpha$-reductase inhibitors used for the prevention of PCa. Three isoforms of $5 \alpha$-reductase have been discovered. While finasteride inhibits types 2 and 3 , resulting in a 70\% inhibition of DHT synthesis, dutasteride inhibits all three isoforms and thereby provides a complete inhibition of DHT synthesis (16). Two clinical trials, one with finasteride (Prostate Cancer Prevention Trial (PCPT)) and another with dutasteride (Reduction by Dutasteride of Prostate Cancer Events (REDUCE)), demonstrated a $25 \%$ reduction in $\mathrm{PCa}$ incidence (17). However, some controversy and conflicting opinion on the development of high-grade PCa resulted in the skepticism in the use of $5 \alpha$-reductase inhibitors in treating PCa.

\section{Cyp17A1 inhibitor}

Another androgen-synthesizing enzyme CYP17A1 was also used as a therapeutic target to treat PCa. Abiraterone acetate (AA) is an inhibitor of the cytochrome P450 c17 gene (CYP17A1) family of enzymes that are important for steroidogenesis $(18,19)$. The active metabolite of AA, abiraterone, acts as a potent inhibitor of CYP17 enzyme (20). AA was tested in a phase III clinical trial in 1195 men with CRPC who had previously received docetaxel (21). As AA inhibits Cyp17 enzyme, which is upstream in the synthesis of several hormones, one of the problems inherent in this inhibition is corticosteroid deficiency (22). This had to be overcome by co-administering prednisone with the aim to prevent the reflex of adrenocorticotropic hormone (ACTH) increase and reduce the severity of mineralocorticoidrelated side effects, seen with abiraterone alone. The results showed that median survival increased to 14.8 months in the AA group compared to 10.9 months in the placebo group, and median time for PSA progression increased from 6.6 months to 10.2 months (21). Unfortunately, patients treated with abiraterone experience a relapse of CRPC within 2 years after treatment (23).

\section{AR antagonists}

Since the above indicated drugs limit the availability of ligands to the AR, inhibiting the AR with antagonists could be a direct mechanism and a distinct strategy to reduce the growth of PCa or CRPC.

\section{Bicalutamide and hydroxy-flutamide}

Bicalutamide (Casodex) and flutamide (the active metabolite of flutamide is hydroxy-flutamide) are non-steroidal first-generation antiandrogens that competitively inhibit the AR by outcompeting androgens for the active site (24). While flutamide was approved in 1983, bicalutamide was approved in 1995. Bicalutamide and flutamide are not widely used now due to the discovery of more potent next-generation AR antagonists. Mutations in the AR LBD cause resistance to bicalutamide and flutamide (25). While W741 mutation results in resistance to bicalutamide, T877 mutation causes resistance to flutamide (26). Both these mutations convert the antagonists to partial agonists.

\section{Second-generation AR antagonists (enzalutamide and apalutamide)}

Discovery of enzalutamide in the 2000s created a renewed interest in the field of AR antagonists. Enzalutamide and the structurally related apalutamide are both considered to be more potent AR antagonists compared to bicalutamide or flutamide $(27,28,29)$. While the first-generation antagonists inhibit the AR activity by competitively binding to the AR LBD, promoting nuclear localization and recruiting corepressors instead of coactivators, the second-generation AR antagonists such as enzalutamide competitively bind to the AR LBD and inhibit nuclear translocation (28). This provides a mechanistic advantage to these molecules as they prevent any inadvertent activation of the nuclear AR by any alternate signaling pathways.

Enzalutamide is approved for the treatment of CRPC pre and post chemotherapy (30). Administered orally, and similar to AA, enzalutamide treatment has shown an increased overall survival in patients with metastatic CRPC, as well as increased PSA progression time and radiographic progression-free survival (rPFS) before receiving chemotherapy (30). The pivotal phase III clinical trial with enzalutamide (AFFIRM) provided an overall survival of 18.4 months in the enzalutamide-treated group (30), while the placebo group had an overall survival of 13.6 months. All secondary endpoints such as time taken for PSA progression, PFS and other such measures showed significantly better results in the enzalutamidetreated group compared to the placebo group. While enzalutamide won its marketing approval in 2012, the structurally similar apalutamide was approved in 2017. Both enzalutamide and apalutamide are resistant to the AR that expresses F876L mutation (31). This mutation has been shown to convert the two drugs into partial agonists, resulting in a relapse of the cancer.
This work is licensed under a Creative Commons Attribution-NonCommercial 4.0 International License. ded from Bioscientifica.com at 04/26/2023 01:48:15PM via free access 


\section{Mechanistically distinct AR-targeting molecules in preclinical stage}

Few molecules that are mechanistically distinct from the currently marketed AR antagonists are under development. One of the mechanisms for the relapse of $\mathrm{PCa}$ from the treatment of enzalutamide and AA is the expression of AR splice variants (AR-SVs) (32). AR-SVs (most commonly detected AR-SV in the clinic is AR-V7) have been detected in $25-30 \%$ of the PCa patients treated with AA or enzalutamide. Since AR-SVs lack LBD, the protein is constitutively active and drives CRPC growth aggressively (33).

Since there is no binding pocket to inhibit the AR-SVs, it was considered as therapeutically non-targetable. However, the discovery of EPI-001 in 2010 provided some hope that a binding region that is distinct from the AR LBD and is expressed in the N-terminus domain of the AR is available to target the AR-SVs (34). Although an analog of EPI-001, EPI-506, failed in a phase I clinical trial, another class of molecules, the sintokamides, possess properties similar to EPI compounds, and some members of this family are likely to enter clinical trials (35).

Another group of molecules that bind to the AR-AF-1 and degrade the AR was recently disclosed. These molecules are extremely potent AR antagonists that bind to the AR-NTD and degrade the AR and AR-SV at submicromolar to nanomolar doses (36). These molecules (UT-69 and UT-155) ubiquitinate and proteasomally degrade the AR and AR-SV at therapeutically manageable doses.

Degraders such as PROTAC (Proteolysis Targeting Chimera), SNIPERS (Non-genetic inhibitor of apoptosis protein (IAP)-dependent protein erasers) and others that recruit ubiquitin ligases to the AR complex are advancing through preclinical stages for the treatment of CRPC (37, 38). As these chimeric molecules have not been tested in the patients, the success of these hybrid technologies will be determined only after a successful completion of a proof-of-concept clinical trial.

\section{Non-AR-targeted therapeutics}

Although more than $90-95 \%$ of PCas express AR, nonAR-targeted treatments are also available to patients who have relapsed from AR-targeted treatments or those who suffer from non-AR-expressing PCas, such as the neuroendocrine subtype.

\section{Cabazitaxel}

Cabazitaxel (Jevtana) acts by stabilizing microtubules and thereby inducing apoptosis (39). Open-label and randomized trials in mCRPC patients with either $25 \mathrm{mg} / \mathrm{m}^{2}$ of cabazitaxel alone or in combination with $12 \mathrm{mg} / \mathrm{m}^{2}$ of mitoxantrone and $10 \mathrm{mg} /$ day of prednisone every 3 weeks led to the approval of cabazitaxel (40). Taxanes, including cabazitaxel, have high affinity for microtubules, preventing cell division and mitosis. In addition, taxanes also prevent $\mathrm{AR}$ nuclear localization (41). Cabazitaxel also has a lower affinity for the p-glycoprotein drug efflux pump, which causes resistance to drugs (42).

\section{Sipuleucel-T}

Sipuleucel-T (Provenge) is the first autologous immunotherapy treatment to be approved by the Food and Drug Administration (FDA) (43). It is a personalized treatment and is called a therapeutic vaccine. To clinically manufacture sipuleucel-T, peripheral blood mononuclear cells (PBMC) from a patient (43), including antigenpresenting cells (APC), will be activated with a prostatic acid phosphatase (PAP)-containing recombinant fusion protein (43). The activated blood cells are then infused back into the patient, which causes an immune response selectively in the prostate, since PAP is found only in the prostate. Unfortunately, due to higher cost (approximately $\$ 100,000$ for a course of three infusions), sipuleucel-T is not widely prescribed.

\section{Clinical trial candidates}

As of now, few novel agents for the treatment of PCa are undergoing clinical trials. Orteronel, a novel hormone, is in phase III clinical trials in men with early stages of PCa (44). It functions as an inhibitor of the cytochrome P450 17, 20 lyase (CYP17A1) protein. Since CYP17A1 is vital for androgen synthesis, inhibiting the enzyme could result in shrinking of the prostate gland. The latest update on the drug suggests that it failed to increase the survival of the patients and its development has been halted. Everolimus is a mammalian target of rapamycin (mTOR) inhibitor that has completed phase II clinical trials (45). In a phase II clinical trial, everolimus combined with bicalutamide has been administered orally to patients with progressive mCRPC. So far, this treatment regimen has shown some positive effects.
This work is licensed under a Creative Commons Attribution-NonCommercial 4.0 International License. ded from Bioscientifica.com at 04/26/2023 01:48:15PM via free access 


\section{Conclusion}

Many potential therapeutic targets are on the horizon that may help PCa patients. In a cross-species study conducted during 2018, ten potential therapeutic targets have been found (46). In another study conducted in 2017, STAT3 and STAT5A have also been shown to be potential therapeutic targets (47). Ninety-three percent of CRPC cases have shown strong immunoreactivity for STAT3, and $80 \%$ of CRPC cases have shown strong immunoreactivity for STAT5A. In addition, adiponectin, a protein that belongs to the adipokine family regulating angiogenesis, metabolism and inflammation, has been identified as a potential therapeutic target (48). In patients with CRPC, adiponectin levels are lower than normal. Contrastingly, an increased level of adiponectin has led to resistance against PCa growth. Overall, the PCa and CRPC therapeutic landscape is evolving and in the next decade urologists and oncologists will have an armamentarium of drugs available for prescription to patients who relapse from the existing therapeutics.

\section{Breast cancer}

\section{Background and classification}

Breast cancer is the most common cancer diagnosed in women around the world. In 2012, about 1.7 million women were diagnosed with breast cancer globally (49). In the United States, more than 200,000 women are diagnosed with breast cancer each year and around 40,000 die of the disease (1). Breast cancer is a heterogeneous disease, which is classified based on the expression of therapeutic targets and proliferation rate of the epithelial cells in the tumor. The standard classification of breast cancer involves the assessment of the expression of steroid and growth factor receptors, $\mathrm{ER} \alpha$, progesterone receptor (PR) and human epidermal growth factor receptor (HER2) in the primary tumor, in combination with the proliferation marker Ki-67 (50). Over the last half century, survival of women with breast cancers has increased substantially around the world due to the discovery and development of disease-modifying novel therapeutics.

\section{Therapeutics for hormone receptor-positive breast cancer}

Tumors that are positive for ER and PR are typically treated with drugs that target the estrogen signaling. Two classes of drugs are available, with one directly antagonizing or degrading the ER in breast cancer cells and the other inhibiting the enzyme aromatase, which is important for the synthesis of estradiol, the primary circulating estrogen, from testosterone.

\section{ER-targeting agents}

ER-modulating compounds are typically selective estrogen receptor modulators (SERMs) or selective estrogen receptor degraders (SERDs). The FDA-approved SERMs for treating breast cancer are the first-generation SERMs tamoxifen and toremifene, which have a 30-year history as first-line breast cancer treatments $(51,52)$. The only FDA-approved SERD for the treatment of breast cancer is fulvestrant. Currently, these therapies are approved only for use in the adjuvant setting. In addition to their use as treatments, tamoxifen and another SERM, raloxifene, are also approved for use as preventive agents, although raloxifene is limited to postmenopausal women.

SERMs belong to a class of drugs that activates or inhibits ERs tissue selectively. Tamoxifen functions as an antagonist in breast tissue, rendering anti-proliferative effects. However, tamoxifen is an agonist in the uterus and endometrium thereby increasing the chances of endometrial cancer. Similarly, raloxifene is an antagonist in the breast and uterus, while being an agonist in the bone. This property of raloxifene is considered to have an advantage over tamoxifen. The mechanisms for the tissue selectivity of SERMs have been extensively investigated over the last two decades (53).

\section{Tamoxifen}

Tamoxifen, belonging to the triphenylethylene class of SERMs, was first discovered in 1962 and entered clinical trials to treat breast cancer in the 1970s. Tamoxifen is one of the most prescribed anti-cancer drugs in the world and has substantial long-term safety data associated with it (51). One of the first reported clinical trials of tamoxifen was conducted in 74 patients with two doses of the drug (54). Tamoxifen produced an overall response rate between 40 and 55\% with several partial and complete responses reported in the trials $(55,56)$. The side effects were minimal and the drug was considered to be safe. It is on the current World Health Organization's list of essential medicines.

In 2011, an article compared follow-up data from five clinical trials in women treated with or without tamoxifen (57). Women who received tamoxifen for 5 years had a much lower risk of recurrence during a 15-year follow-up than women who were treated with placebo.

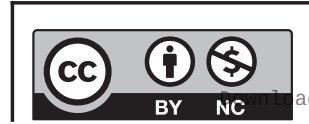

This work is licensed under a Creative Commons Attribution-NonCommercial 4.0 International License. ded from Bioscientifica.com at 04/26/2023 01:48:15PM 
Moreover, the women treated with tamoxifen had a 33\% less risk of dying from breast cancer. These data suggest that tamoxifen is an effective drug in the long term.

The active metabolite of tamoxifen is 4-hydroxy tamoxifen (4-OH-TAM) $(58,59)$. Less than 5\% of tamoxifen is converted to 4-OH-TAM in vivo and the 4-OH-TAM is highly active when compared to the parent compound.

\section{Raloxifene}

Raloxifene belongs to the benzothiophene class of SERMs. It is approved for use in postmenopausal osteoporosis and in breast cancer in women with osteoporosis. The Study of Tamoxifen and Raloxifene (STAR) clinical trials compared the efficacy of tamoxifen and raloxifene in breast cancer (60). About 20,000 women who are at high risk of developing breast cancer in 5 years were randomized and treated with $20 \mathrm{mg} /$ day of tamoxifen or $60 \mathrm{mg} /$ day of raloxifene. The outcomes that were measured include incidence of invasive and non-invasive breast cancers, uterine cancer, fractures and thromboembolism. The outcome suggested that raloxifene was as effective as tamoxifen in reducing the incidence of invasive breast cancers, while it also provided a lower incidence of uterine cancers, fractures and thromboembolic events (60). The study concluded that both SERMs have preventive effects in breast cancer. Despite the outcome of the trial, raloxifene is not widely used to treat breast cancer.

\section{Fulvestrant}

Fulvestrant or ICI 182,780 is a SERD that selectively destroys ER. Fulvestrant binds to the ER LBD, antagonizes the ER and degrades the ER via ubiquitin proteasome pathway (61). Fulvestrant was approved for use in metastatic breast cancer in 2002. Administered via injection, fulvestrant is safe and very effective as a firstline or second-line hormonal therapy. In a clinical trial reported in 1994, fulvestrant administered as a neoadjuvant for 7 days resulted in a significant reduction in ER, PR and ki67 expression in the tumors (62). In another clinical trial, fulvestrant administered as monthly depot demonstrated a 69\% response rate in tamoxifen- resistant breast cancer (63), although this higher response rate was disputed by other groups (64).

\section{Aromatase inhibitors}

The second mode of estrogen disruption used in breast cancers is to target the enzyme that synthesizes estradiol, aromatase. There are three drugs with this mechanism of action currently approved by the FDA for use in breast cancer: anastrozole, exemestane and letrozole (65). All of these function by inhibiting the aromatase enzyme, with anastrozole and letrozole functioning as nonsteroidal reversible aromatase inhibitors and exemestane functioning as an irreversible steroidal aromatase inactivator (65). As these agents cannot block the production of estrogens from ovaries, they are approved for postmenopausal breast cancers only (66). Exemestane has also been suggested for use in premenopausal breast cancers with the TEXT and SOFT trials showing that this drug may be superior to tamoxifen treatment with or without ovarian suppression $(67,68)$. When comparing their efficiency to ER inhibitors in postmenopausal women, all three drugs proved to be more effective than tamoxifen in preventing recurrence (69). Thus, aromatase inhibitors have become the standard treatment in firstline care of postmenopausal breast cancer patients. Comparison of anastrozole and letrozole in the recently completed FACE Trial suggested no measurable clinical benefit of one over the other (70).

The sequence of treatment with these various agents that target estrogen signaling depends on the oncologists' particular protocols. No specific order of use has been prescribed for these agents.

\section{HER2-targeted therapeutics}

For HER2-overexpressing carcinomas, HER2-directed therapy (either through HER2-directed antibodies or downstream tyrosine kinase inhibitors) is typically the avenue of choice. Currently, there are four FDA-approved targeted therapies that inhibit this pathway. The first in this class to win clinical approval was trastuzumab, a monoclonal antibody directed against the HER2 receptor (71). Available clinically for around 20 years, this therapy was one of the first real breakthroughs for specific treatment of HER2-overexpressing breast cancer, although it is not without potential side effects and/or relatively rapid development of resistance $(71,72)$. Used alone, or alongside chemotherapy or endocrine therapy, trastuzumab is used in early and metastatic cancer and approved for use in both adjuvant and neoadjuvant settings. Pertuzumab, another monoclonal antibody similar to trastuzumab, targets the extracellular domain of HER2 and inhibits dimerization with other members of the HER2 family (73). Initially approved by the FDA as a treatment for metastatic breast cancer in 2012 in combination with trastuzumab https://ec.bioscientifica.com https://doi.org/10.1530/EC-18-0425 (c) 2019 The authors Published by Bioscientifica Ltd
This work is licensed under a Creative Commons Attribution-NonCommercial 4.0 International License. ded from Bioscientifica.com at 04/26/2023 01:48:15PM via free access 
and docetaxel chemotherapy (73), it has recently (2017) been approved in the adjuvant setting in tandem with chemotherapy and trastuzumab on the basis of the results of the APHINITY trial (74).

Lapatinib is a tyrosine kinase inhibitor, and hence, has a different mechanism of action than the two drugs listed above (75). It works by binding the tyrosine kinase domain of the HER2 (and HER1) receptors, thus preventing downstream signaling. First approved by the FDA in 2007 for the treatment of metastatic HER2-positive breast cancers, its suggested use is after chemotherapy and trastuzumab therapy have failed (76). The final FDAapproved therapy (approved 2013) for HER2-expressing breast cancer is ado-trastuzumab emtansine (T-DM1) (77). It is based on the conjugation of trastuzumab to the tubulin-specific cytotoxic agent emtansine, with the logic being that trastuzumab will both inhibit the growth of cancer cells and localize the cytotoxic treatment. It is currently only approved in the metastatic setting after previous treatments have failed. Its approval was made on the basis of the EMILIA trial (78). While clinical trials have attempted to assess its potential as a first-line therapy against metastatic breast cancer, they failed to demonstrate a benefit over trastuzumab and chemotherapy treatment (MARIANNE trial) (79).

\section{Triple-negative breast cancer therapeutics}

No standard targeted therapy exists for TNBC, and chemotherapeutic approaches are typically the primary methods used in treatment. While the optimal chemotherapeutic regimen remains a matter of debate, the current consensus seems to favor an anthracycline/taxanecontaining regimen with the possibility of the DNAdamaging platinum agents becoming potentially more important, although this opinion is far from consensus (80). As touched on above, TNBC is inherently a diverse sub-classification (81), and many preclinical studies and early clinical trials are now focusing on therapies in subpopulations of TNBC. It is yet unclear how the subtypespecific approaches will perform in the clinic. However, several studies are proving that patient selection and methods of identifying subgroups are important for the success of these experimental therapeutics.

\section{New breast cancer therapeutics currently in the clinical setting}

In the last decade, few new therapeutics, including CDK4/6, mTOR and PARP inhibitors, have been developed.
In addition to these, immunotherapy for breast cancers has recently been gaining traction.

\section{CDK4/6 inhibitors}

CDK4/6 is cyclin-dependent kinases that are central to the proliferation of all cells. Their functions are important for the transition of the cells between the G1 and S phases of the cell cycle; thus, it was hypothesized that their inhibition would arrest the growth of cancer cells (82). CDK4/6 inhibitors were expected to be selective to cancer cells due to their overexpression in cancer cells compared to normal cells and due to the fact that rapidly proliferating cells will be more susceptible to inhibition.

Palbociclib, ribociclib and abemaciclib are the three CDK4/6 inhibitors approved for use. Initially, CDK4/6 therapy was focused on the postmenopausal, HR-positive advanced or metastatic breast cancer setting and was tested in three main clinical trials; the PALOMA 1, 2 and 3 trials (palbociclib) $(83,84,85)$, the MONALEESA-2 and 7 trials (ribociclib) $(86,87)$ and the MONARCH -1 , 2 and 3 trials (abemaciclib) $(88,89)$. Palbociclib and ribociclib were tested in combination with standard estrogen-directed therapy (letrozole) and compared to standard therapy alone. Abemaciclib's efficacy was assessed in combination with fulvestrant. In all cases, the combination therapy outperformed the standard therapy alone, with a significant increase in PFS. On the basis of these results, the FDA approved the use of palbociclib and ribociclib in combination with letrozole in HER2-negative advanced breast cancers in 2015 and 2017, and abemaciclib in combination with fulvestrant in ER-positive, HER2-negative metastatic cancers or alone in cancers that are refractory to hormone treatment in 2017.

\section{mTOR inhibitors}

mTOR is a key protein that integrates a number of signals (90). Temsirolimus and everolimus are the two leading agents targeting the mTOR pathway. Of these two, everolimus has been adopted in the clinical setting in breast cancers. The successful outcome from the BOLERO-2 trial suggested the use of this mTOR inhibitor in breast cancers (91). These trials were conducted in postmenopausal women who were ER positive and HER2 negative and had progressed on endocrine therapy. Everolimus was tested against endocrine therapy alone (exemestane) or in combination with endocrine therapy. An increase in PFS was observed in the combination group. Everolimus in combination with exemestane was approved by the US

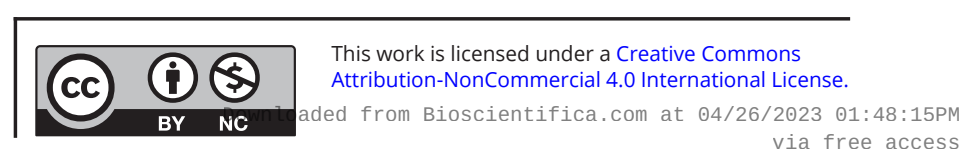


FDA in HR-positive HER2-negative breast cancer patients who had progressed on endocrine therapy. Similar to the CDK4/6 inhibitors, preclinical evidence suggested that these agents may be effective in other breast cancer subtypes, such as early-stage TNBC (92).

\section{Poly (ADP-ribose) polymerase (PARP) inhibitors}

PARP binds and aids in base excision repair of singlestranded DNA breaks. Inhibition of PARP leads to doublestrand DNA breaks and ultimately cell death in cells unable to effectively repair double-strand DNA breaks. BRCA1 and BRCA2 proteins are integral components of the homologous repair system, the primary doublestranded DNA break repair mechanism (93). Mutations in BRCA1 and/or BRCA2, or any other protein within the homologous repair (HR) system, results in a reliance on non-homologous end-joining repair (NHEJ). NHEJ is error prone, and reliance on NHEJ is ineffective in repairing DNA damage on a large scale, ultimately resulting in cytotoxicity (94). Approximately 10\% of all patients with breast cancer and about 30\% of patients with hereditary breast cancer harbor a germline BRCA1 or BRCA2 mutation (95). Given this, PARP inhibitors were and are a logical choice for the development of targeted therapy in breast cancer. While many inhibitors have been developed against PARP, only one of these has been approved for use in breast cancer. Olaparib was assessed in patients with metastatic breast cancer with germline mutations in BRCA1 or 2. It was assessed as a single agent and compared to a standard chemotherapy (agent not specified, physician's choice) (96). In this setting, olaparib showed a significant PFS benefit and was approved by the FDA for use in BRCA-mutated HER2-negative metastatic breast cancers in early 2018.

\section{Immunotherapy}

Immunotherapy is considered as a breakthrough therapy for cancers in general. The logic behind this research is that the growth and progression of cancer is due in part to the immune system's inability to correctly identify the abnormal cells associated with cancer progression. Altering this balance to allow immune recognition of cancerous cells may lead to the body responding and managing the tumor. At present, there is only one agent in this category that has been approved by the FDA for use in solid tumors, including breast cancers, and that is the PD-1/PDL-1 inhibitor pembrolizumab. Its approval for use is linked to specific genetic markers (high microsatellite instability, mismatch repair deficiency) in cancers that have progressed following prior treatment with no satisfactory treatment options. Multiple clinical trials are currently addressing its specific role in breast cancer progression, across a number of different subtypes and settings with the results of these trials expected by 2020 .

\section{Ovarian cancer}

\section{Background}

Ovarian cancer is one of the endocrine cancers that affects approximately 22,000 women and results in 14,000 deaths annually in the United States (1). Although it is the second most common malignancy of the female reproductive tract, it is responsible for the majority of deaths from gynecologic malignancies (97). The poor prognosis of ovarian cancer is predominantly due to diagnosis at advanced stages and the high frequency of recurrence following adjuvant chemotherapy (98). Ovarian cancer is heterologous with distinct histologic subtypes that differ in clinical outcomes and require individualized therapies (99).

\section{Classification of ovarian cancer}

Ovarian cancer is categorized by anatomical location into epithelial, stromal and germ cell malignancies (100). Epithelial ovarian cancer, which arises from the surface epithelium of the ovary, accounts for $90 \%$ of all ovarian cancer. It can be further subcategorized into serous, endometrioid, clear cell, mucinous, transitional cell and mixed adenocarcinomas (101). High-grade serous ovarian cancer (HGSOC) is the most common ovarian malignancy, comprising 70-80\% of ovarian serous cancers and closely resembles the epithelium of the fallopian tube (102). The molecular profile of HGSOC is unique, exhibiting a high rate of HR exemplified by mutations in BRCA1, BRCA2 and TP53 (103).

\section{Therapeutic options for ovarian cancer}

There is some debate as to whether the initial management of advanced ovarian cancer should be with neoadjuvant chemotherapy (NACT) followed by interval debulking surgery or with primary debulking surgery (PDS) followed by adjuvant chemotherapy. Patients should undergo PDS whenever possible, and NACT should be reserved for those who cannot tolerate PDS and/or optimal cytoreduction is (c) 2019 The authors Published by Bioscientifica Ltd
This work is licensed under a Creative Commons Attribution-NonCommercial 4.0 International License. ded from Bioscientifica.com at 04/26/2023 01:48:15PM 
not possible, as optimal PDS is associated with significantly better survival compared to NACT (104).

\section{Chemotherapy}

Patients who are not candidates for PDS should receive NACT using combination of intravenous carboplatin and paclitaxel prior to interval debulking surgery, followed by adjuvant intravenous carboplatin and paclitaxel (105, 106). A recent randomized controlled trial showed a significant benefit of heated intraperitoneal chemotherapy (HIPEC) given at the time of interval debulking surgery. This improved the overall survival in patients who received NACT by 11.8 months (107). Although results of this trial are promising, there were serious limitations that require further evaluation before HIPEC is ready for widespread use (108).

Initial therapy for epithelial ovarian cancer consisted of i.p. radioactive $\mathrm{P}$ (32), oral melphalan and combination IV cisplatin/cyclophosphamide (109, 110). Although the efficacy of platinum therapy was identified in early Gynecologic Oncology Group (GOG) trials, combination platinum/taxane for adjuvant treatment of ovarian cancer was not established until 1996 following the results of GOG 111 (111). Cisplatin/paclitaxel remained the standard of care for 7 years until the GOG published the results of a non-inferiority trial in 2003, establishing carboplatin/ paclitaxel as the current chemotherapeutic backbone used today for the treatment of epithelial ovarian cancer (112). Cisplatin and carboplatin are DNA-alkylating agents that preferentially bind guanine residues of double-stranded DNA and crosslinks DNA adducts, interfering with mitosis (113). Platinum/taxane in combination synergistically works to inhibit tumor growth and trigger apoptosis in rapidly dividing cells, resulting not only in the death of tumor cells but producing myelosuppression, alopecia and gastrointestinal side effects (112). Details of combination chemotherapy can be found in Supplementary Table 1 (see section on supplementary data given at the end of this article).

\section{Targeted therapeutics}

The introduction of anti-angiogenesis inhibition for ovarian cancer therapy in 2011 represented the first novel drug class shown to be effective in ovarian cancer since the introduction of paclitaxel in 1996 (114). Two phase III trials, GOG 218 and ICON7, evaluated bevacizumab with platinum/taxane chemotherapy for the treatment of ovarian cancer in the adjuvant setting following
PDS. Both trials found maintenance bevacizumab improved progression-free survival (PFS) without prolonging overall survival (OS), a common trend with antiangiogenic therapy for ovarian cancer. Although the investigators did not find an OS benefit in all patients, subset analysis of patients who had suboptimal primary cytoreduction exhibited an OS benefit with the addition of bevacizumab, perhaps representing an alternative to the 'dose-dense' taxane regimen that showed a significant survival benefit among sub-optimally debulked patients $(114,115,116)$. Pazopanib (an inhibitor of c-KIT, FGFR, PDGFR and VEGFR tyrosine kinases) and nintedanib (a small molecular inhibitor of PDFGR, FGFR and VEGFR) have both been evaluated in the phase III setting and showed outcomes similar to bevacizumab $(117,118)$. While there is a debate among specialty centers regarding the most effective platinum/taxane regimen for advanced ovarian cancer, maintenance anti-angiogenesis for patients who received optimal PDS is yet to be approved by the FDA (119).

About $85 \%$ of advanced epithelial ovarian cancers respond initially to adjuvant platinum/taxane therapy. Unfortunately, about $75 \%$ of those patients who initially respond experience recurrence (120). Multiple combinations have been evaluated for the treatment of platinum-sensitive recurrent epithelial ovarian cancer (Supplementary Table 2).

PARPi (PARP inhibitors) is the first FDA-approved treatment using the concept of synthetic lethality in the treatment of epithelial ovarian cancer. Although only $10-15 \%$ of patients with HGSOC have a germline BRCA1 or BRCA2 mutation, approximately $50 \%$ of patients have tumors that exhibit a homologous recombination deficiency from either a germline or somatic mutation in the HR system (121). Multiple studies have evaluated PARPi in the maintenance setting following carboplatin and paclitaxel for platinum-sensitive recurrent epithelial ovarian cancer and have shown a significant benefit in PFS in all patients, especially those with BRCA mutations or having HR deficiency (somatic or germline). Although both breast and ovarian cancers exhibit HR deficiency, response to PARPi therapy is significantly better in patients with ovarian cancer compared to those with breast cancer who harbor a germline BRCA1 or BRCA2 mutation (122). Data on OS for patients with ovarian cancer receiving PARPi in the maintenance setting are still not mature and there is currently significant debate on whether maintenance bevacizumab or PARPi is appropriate following carboplatin and paclitaxel for treatment of platinum-sensitive recurrent epithelial ovarian cancer.

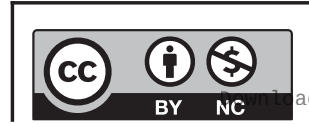


Patients who have platinum-resistant or refractory disease unfortunately have limited effective options. Given poor response rates for chemotherapy and the desire to minimize toxicity, single-agent chemotherapy has been the mainstay in this subset of patients (123). The addition of antiangiogenic therapy to single-agent cytotoxic chemotherapy has been shown to improve response rates and PFS (124) (Supplementary Table 3). PARPi has also been shown to be of benefit to patients with germline or somatic mutations in BRCA and represents a well-tolerated option in eligible patients (125). Tamoxifen, letrozole, fulvestrant and angiogenesis inhibitors have also been evaluated for use in the platinum-resistant setting with responses similar or worse than cytotoxic chemotherapy $(126,127,128,129,130)$.

\section{Drugs under development for ovarian cancer}

Many clinical trials are currently underway evaluating treatments of epithelial ovarian cancer in both the adjuvant and recurrent setting (Supplementary Table 4). The PI3K/AKT/mTOR pathway plays an important role in cellular signaling controlling multiple processes including angiogenesis, proliferation, protein synthesis and cell survival (131). The MAPK pathway is also an active area of phase I/II research, as it has been shown to regulate cell cycle progression, metabolism, differentiation and cell survival in borderline tumors of the ovary and low-grade serous ovarian cancer (LGSOC) (132). Folate receptors have been shown to be upregulated in ovarian cancer and antagonists are currently in phase I and II clinical trials
(133). Human epidermal growth factor receptor (HER) has been implicated in the pathogenesis of epithelial ovarian cancer and both trastuzumab and pertuzumab, humanized monoclonal antibodies against HER2, have been evaluated in phase II and III settings (134). Immunotherapy has also been studied in recurrent ovarian cancers and is currently being evaluated in phase III trials (135). Novel combinations of PARPi, antiangiogenic drugs, inhibitors of the MAPK pathway, PI3K inhibitors and conventional chemotherapy are currently in early phases of development.

There are currently a multitude of phase I, II and III trials evaluating individualized, targeted therapies in hopes of providing significant survival improvements not seen since the introduction of platinum chemotherapy over 20 years ago.

\section{Therapeutic target crossover}

Although this review provides the usefulness of the various therapeutic targets in independent cancers, desperate need for novel therapeutic agents for cancers that are refractory to standard of care pushes the boundary to evaluate the functional crossovers of the targets in other cancers (Fig. 3).

Although the role of androgens and $\mathrm{AR}$ is undisputedly established in PCa over the last century, their role in breast and ovarian cancers is yet to be defined beyond doubt. Studies have indicated that AR is the most abundant receptor in breast cancer, expressed in

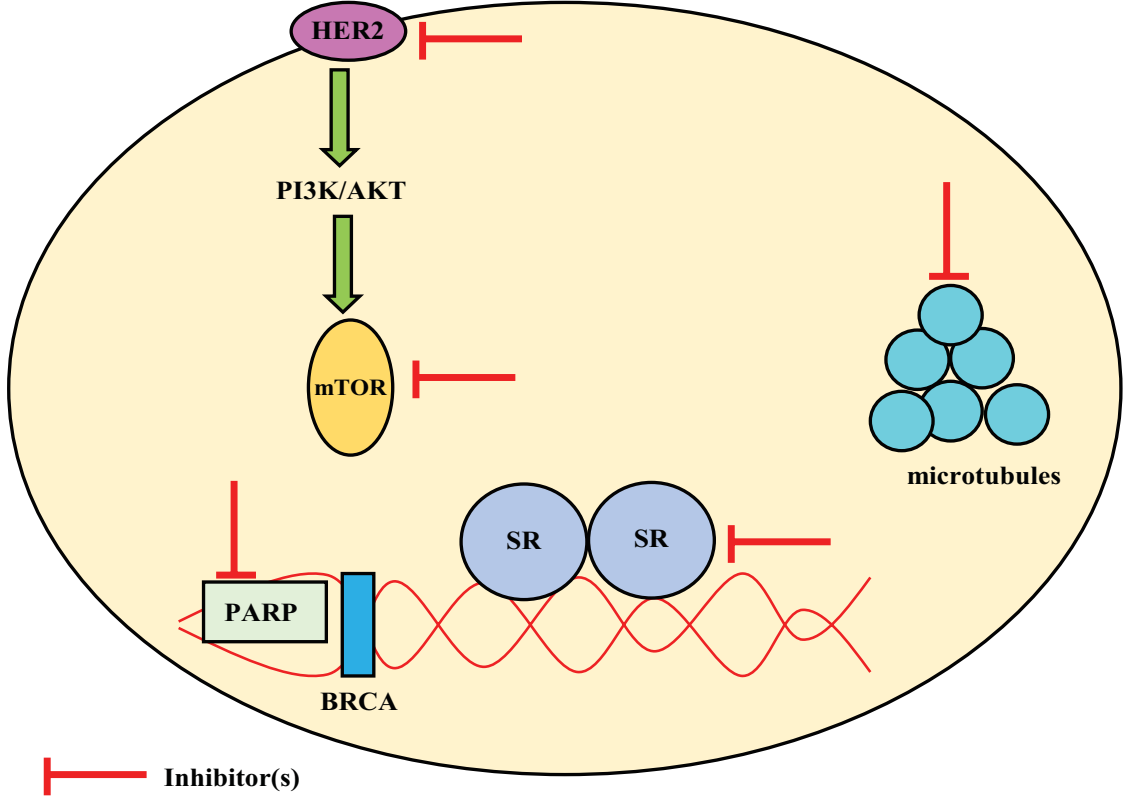

Figure 3

Various therapeutic targets and growthpromoting proteins common to prostate, breast and ovarian cancers. https://ec.bioscientifica.com https://doi.org/10.1530/EC-18-0425 (c) 2019 The authors Published by Bioscientifica Ltd
This work is licensed under a Creative Commons Attribution-NonCommercial 4.0 International License. ded from Bioscientifica.com at 04/26/2023 01:48:15PM 
Table 1 List of drugs and drug targets.

\begin{tabular}{l} 
Drugs \\
\hline Finasteride, dutasteride \\
Leuprolide, degarelix \\
Bicalutamide, enzalutamide, apalutamide \\
Abiraterone acetate \\
Cabazitaxel \\
Sipuleucel \\
Tamxoxifen, raloxifene, toremifene, fulvestrant \\
Anastrazole, exemestane, letrozole \\
Transtuzumab \\
Anthracycline/taxane \\
Palbociclib, ribocyclib, abemaciclib \\
Everolimus \\
Olaparib \\
Pembrolizumab \\
Cisplatin/cyclophosphamide \\
Paclitaxel
\end{tabular}

\begin{tabular}{l} 
Target \\
\hline 5- $\alpha$ reductase inhibitor \\
LHRH agonist and antagonist \\
AR antagonists \\
Cyp17A1 inhibitor \\
Taxanes \\
Immunotherapy
\end{tabular}

Aromatase inhibitors HER2 inhibitor Chemotherapy CDK4/6 inhibitors mTOR inhibitor

PARP inhibitor

Immunotherapy Chemotherapy

\begin{tabular}{l} 
Disease \\
\hline Prostate cancer \\
Prostate cancer \\
Prostate cancer \\
Prostate cancer \\
Prostate cancer \\
Prostate cancer \\
Hormone receptor-positive breast cancer \\
Ovarian cancer \\
Hormone receptor-positive breast cancer \\
HER2-positive breast cancer \\
Triple-negative breast cancer \\
Hormone receptor-positive breast cancer \\
Hormone receptor-positive breast cancer \\
Ovarian cancer \\
Hormone receptor-positive breast cancer \\
Ovarian cancer \\
Breast cancer \\
Ovarian cancer
\end{tabular}

Prostate cancer

Prostate cancer

Prostate cancer

Prostate cancer

Prostate cancer

Prostate cancer

Ovarian cancer

Hormone receptor-positive breast cancer

Hormone receptor-positive breast cancer Hormone receptor-positive breast cancer

Breast cancer

Ovarian cancer even higher number of patients than ER. This expression makes it a valuable therapeutic target in breast cancers $(136,137)$. AR antagonists enzalutamide and bicalutamide have been tested in women with TNBCs (138). AA was evaluated clinically in women with breast cancer (139). Similarly, leuprolide was tested clinically in combination with tamoxifen in hormone receptor-positive breast cancer (140). Although, they are not approved yet, they establish the importance of androgens and AR in breast cancers.

While the role of PARP in breast and ovarian cancers is known, recent clinical trial with the PARPi olaparib in patients with PCa who failed to respond to standard therapy suggests an important role for this therapeutic target in PCa (141). Similarly, preclinical evaluation of CDK4/6 inhibitors in patient-relevant models of prostate cancer provided positive results (142). The various therapeutic targets and proteins that promote the growth of these cancers are captured in Fig. 3.

\section{Summary}

As stated in this review, treatments for the cancers mentioned above have come a long way since the $1970 \mathrm{~s}$ and 1980s. More focused, less toxic and highly effective therapies have evolved over the last decade. The treatment options are listed in Table 1. Developing innovative therapies has been made possible due to extensive research and better understanding of the molecular mechanisms of action of these cancers. There is great hope that these cancers will be managed with better next-generation advanced therapeutics. As has been consistently observed over the last decade, the number of deaths due to these cancers will continue to fall due to effective advanced treatment options.

\section{Supplementary data}

This is linked to the online version of the paper at https://doi.org/10.1530/ EC-18-0425.

\section{Declaration of interest}

$\mathrm{KM} \mathrm{M}$ is an editor of the journal. The other authors declare that there is no conflict of interest that could be perceived as prejudicing the impartiality of this review.

\section{Funding}

This work did not receive any specific grant from any funding agency in the public, commercial or not-for-profit sector.

\section{References}

1 Siegel RL, Miller KD \& Jemal A. Cancer statistics, 2018. CA: A Cancer Journal for Clinicians 201868 7-30. (https://doi.org/10.3322/ caac. 21442)

2 Pollock PA, Ludgate A \& Wassersug RJ. In 2124, half of all men can count on developing prostate cancer. Current Oncology 201522 10-12. (https://doi.org/10.3747/co.22.2102)

3 Katsogiannou M, Ziouziou H, Karaki S, Andrieu C, Henry de Villeneuve $\mathrm{M} \&$ Rocchi P. The hallmarks of castration-resistant prostate cancers. Cancer Treatment Reviews 201541 588-597. (https:// doi.org/10.1016/j.ctrv.2015.05.003)

4 Stark JR, Perner S, Stampfer MJ, Sinnott JA, Finn S, Eisenstein AS, Ma J, Fiorentino M, Kurth T, Loda M, et al. Gleason score and lethal prostate cancer: does $3+4=4+3$ ? Journal of Clinical Oncology 200927 3459-3464. (https://doi.org/10.1200/JCO.2008.20.4669) 
5 Brawley OW. Trends in prostate cancer in the United States. Journal of the National Cancer Institute Monographs 20122012 152-156. (https:// doi.org/10.1093/jncimonographs/lgs035)

6 Semenas J, Allegrucci C, Boorjian SA, Mongan NP \& Persson JL. Overcoming drug resistance and treating advanced prostate cancer. Current Drug Targets 201213 1308-1323. (https://doi. org/10.2174/138945012802429615)

7 Davies AH, Beltran H \& Zoubeidi A. Cellular plasticity and the neuroendocrine phenotype in prostate cancer. Nature Reviews Urology 201815 271-286. (https://doi.org/10.1038/nrurol.2018.22)

8 Ferraldeschi R, Welti J, Luo J, Attard G \& de Bono JS. Targeting the androgen receptor pathway in castration-resistant prostate cancer: progresses and prospects. Oncogene 201534 1745-1757. (https://doi. org/10.1038/onc.2014.115)

9 Alex AB, Pal SK \& Agarwal N. CYP17 inhibitors in prostate cancer: latest evidence and clinical potential. Therapeutic Advances in Medical Oncology 20168 267-275. (https://doi. org $/ 10.1177 / 1758834016642370$ )

10 de Leeuw R, Berman-Booty LD, Schiewer MJ, Ciment SJ, Den RB, Dicker AP, Kelly WK, Trabulsi EJ, Lallas CD, Gomella LG, et al. Novel actions of next-generation taxanes benefit advanced stages of prostate cancer. Clinical Cancer Research 201521 795-807. (https:// doi.org/10.1158/1078-0432.CCR-14-1358)

11 Millar RP, Lu ZL, Pawson AJ, Flanagan CA, Morgan K \& Maudsley SR. Gonadotropin-releasing hormone receptors. Endocrine Reviews 2004 25 235-275. (https://doi.org/10.1210/er.2003-0002)

12 Pitteloud N, Dwyer AA, DeCruz S, Lee H, Boepple PA, Crowley WF Jr \& Hayes FJ. Inhibition of luteinizing hormone secretion by testosterone in men requires aromatization for its pituitary but not its hypothalamic effects: evidence from the tandem study of normal and gonadotropin-releasing hormone-deficient men. Journal of Clinical Endocrinology and Metabolism 200893 784-791. (https://doi. org/10.1210/jc.2007-2156)

13 Ogawa T, Dobrinski I, Avarbock MR \& Brinster RL. Leuprolide, a gonadotropin-releasing hormone agonist, enhances colonization after spermatogonial transplantation into mouse testes. Tissue and Cell 199830 583-588. (https://doi.org/10.1016/S00408166(98)80039-6)

14 Rick FG, Block NL \& Schally AV. An update on the use of degarelix in the treatment of advanced hormone-dependent prostate cancer OncoTargets and Therapy 20136 391-402. (https://doi.org/10.2147/ OTT.S32426)

15 Sharifi N. The 5alpha-androstanedione pathway to dihydrotestosterone in castration-resistant prostate cancer. Journal of Investigative Medicine $2012 \mathbf{6 0}$ 504-507. (https://doi.org/10.2310/ JIM.0b013e31823874a4)

$16 \mathrm{Kim}$ EH, Brockman JA \& Andriole GL. The use of 5-alpha reductase inhibitors in the treatment of benign prostatic hyperplasia. Asian Journal of Urology 20185 28-32. (https://doi.org/10.1016/j. ajur.2017.11.005)

17 Musquera M, Fleshner NE, Finelli A \& Zlotta AR. The REDUCE trial: chemoprevention in prostate cancer using a dual 5alpha-reductase inhibitor, dutasteride. Expert Review of Anticancer Therapy $2008 \mathbf{8}$ 1073-1079. (https://doi.org/10.1586/14737140.8.7.1073)

18 Crona DJ, Milowsky MI \& Whang YE. Androgen receptor targeting drugs in castration-resistant prostate cancer and mechanisms of resistance. Clinical Pharmacology and Therapeutics 201598 582-589. (https://doi.org/10.1002/cpt.256)

19 Ryan CJ \& Cheng ML. Abiraterone acetate for the treatment of prostate cancer. Expert Opinion on Pharmacotherapy 201314 91-96. (https://doi.org/10.1517/14656566.2013.745852)

20 Stein MN, Goodin S \& Dipaola RS. Abiraterone in prostate cancer: a new angle to an old problem. Clinical Cancer Research 201218 1848-1854. (https://doi.org/10.1158/1078-0432.CCR-11-1805)

21 de Bono JS, Logothetis CJ, Molina A, Fizazi K, North S, Chu L, Chi KN, Jones RJ, Goodman OB Jr, Saad F, et al. Abiraterone and increased survival in metastatic prostate cancer. New England Journal of Medicine 2011364 1995-2005. (https://doi.org/10.1056/ NEJMoa1014618)

22 Reid AH, Attard G, Barrie E \& de Bono JS. CYP17 inhibition as a hormonal strategy for prostate cancer. Nature Clinical Practice Urology 20085 610-620. (https://doi.org/10.1038/ncpuro1237)

23 Chen EJ, Sowalsky AG, Gao S, Cai C, Voznesensky O, Schaefer R, Loda M, True LD, Ye H, Troncoso P, et al. Abiraterone treatment in castration-resistant prostate cancer selects for progesterone responsive mutant androgen receptors. Clinical Cancer Research 2015 21 1273-1280. (https://doi.org/10.1158/1078-0432.CCR-14-1220)

24 Furr BJ, Valcaccia B, Curry B, Woodburn JR, Chesterson G \& Tucker H. ICI 176,334: a novel non-steroidal, peripherally selective antiandrogen. Journal of Endocrinology 1987113 R7-R9. (https://doi. org/10.1677/joe.0.113R007)

25 Steinkamp MP, O’Mahony OA, Brogley M, Rehman H, Lapensee EW, Dhanasekaran S, Hofer MD, Kuefer R, Chinnaiyan A, Rubin MA, et al. Treatment-dependent androgen receptor mutations in prostate cancer exploit multiple mechanisms to evade therapy. Cancer Research 200969 4434-4442. (https://doi.org/10.1158/0008-5472. CAN-08-3605)

26 Zhou J, Liu B, Geng G \& Wu JH. Study of the impact of the T877A mutation on ligand-induced helix-12 positioning of the androgen receptor resulted in design and synthesis of novel antiandrogens. Proteins 201078 623-637. (https://doi.org/10.1002/prot.22592)

27 Ito Y \& Sadar MD. Enzalutamide and blocking androgen receptor in advanced prostate cancer: lessons learnt from the history of drug development of antiandrogens. Research and Reports in Urology 2018 10 23-32. (https://doi.org/10.2147/RRU.S157116)

28 Tran C, Ouk S, Clegg NJ, Chen Y, Watson PA, Arora V, Wongvipat J, Smith-Jones PM, Yoo D, Kwon A, et al. Development of a secondgeneration antiandrogen for treatment of advanced prostate cancer. Science 2009324 787-790. (https://doi.org/10.1126/ science.1168175)

29 Clegg NJ, Wongvipat J, Joseph JD, Tran C, Ouk S, Dilhas A, Chen Y, Grillot K, Bischoff ED, Cai L, et al. ARN-509: a novel antiandrogen for prostate cancer treatment. Cancer Research 201272 1494-1503. (https://doi.org/10.1158/0008-5472.CAN-11-3948)

30 Scher HI, Fizazi K, Saad F, Taplin ME, Sternberg CN, Miller K, de Wit R, Mulders P, Chi KN, Shore ND, et al. Increased survival with enzalutamide in prostate cancer after chemotherapy. New England Journal of Medicine 2012367 1187-1197. (https://doi.org/10.1056/ NEJMoa1207506)

31 Balbas MD, Evans MJ, Hosfield DJ, Wongvipat J, Arora VK, Watson PA, Chen Y, Greene GL, Shen Y \& Sawyers CL. Overcoming mutation-based resistance to antiandrogens with rational drug design. eLife 20132 e00499. (https://doi.org/10.7554/eLife.00499)

$32 \mathrm{Xu} \mathrm{J} \&$ Qiu Y. Role of androgen receptor splice variants in prostate cancer metastasis. Asian Journal of Urology 20163 177-184. (https:// doi.org/10.1016/j.ajur.2016.08.003)

33 Antonarakis ES, Lu C, Wang H, Luber B, Nakazawa M, Roeser JC, Chen Y, Mohammad TA, Chen Y, Fedor HL, et al. AR-V7 and resistance to enzalutamide and abiraterone in prostate cancer. New England Journal of Medicine 2014371 1028-1038. (https://doi. org/10.1056/NEJMoa1315815)

34 Andersen RJ, Mawji NR, Wang J, Wang G, Haile S, Myung JK, Watt K, Tam T, Yang YC, Banuelos CA, et al. Regression of castrate-recurrent prostate cancer by a small-molecule inhibitor of the amino-terminus domain of the androgen receptor. Cancer Cell 201017 535-546. (https://doi.org/10.1016/j.ccr.2010.04.027)

35 Banuelos CA, Tavakoli I, Tien AH, Caley DP, Mawji NR, Li Z, Wang J, Yang YC, Imamura Y, Yan L, et al. Sintokamide A is a novel antagonist of androgen receptor that uniquely binds activation function-1 in its amino-terminal domain. Journal of Biological Chemistry 2016291 22231-22243. (https://doi.org/10.1074/jbc. M116.734475)

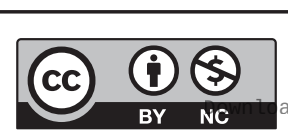

This work is licensed under a Creative Commons Attribution-NonCommercial 4.0 International License. ded from Bioscientifica.com at 04/26/2023 01:48:15PM 
36 Ponnusamy S, Coss CC, Thiyagarajan T, Watts K, Hwang DJ, He Y, Selth LA, McEwan IJ, Duke CB, Pagadala J, et al. Novel selective agents for the degradation of androgen receptor variants to treat castration-resistant prostate cancer. Cancer Research $2017 \mathbf{7 7}$ 6282-6298. (https://doi.org/10.1158/0008-5472.CAN-17-0976)

37 Raina K, Lu J, Qian Y, Altieri M, Gordon D, Rossi AM, Wang J, Chen X, Dong H, Siu K, et al. PROTAC-induced BET protein degradation as a therapy for castration-resistant prostate cancer. PNAS 2016113 7124-7129. (https://doi.org/10.1073/ pnas.1521738113)

38 Shibata N, Nagai K, Morita Y, Ujikawa O, Ohoka N, Hattori T, Koyama R, Sano O, Imaeda Y, Nara H, et al. Development of protein degradation inducers of androgen receptor by conjugation of androgen receptor ligands and inhibitor of apoptosis protein ligands. Journal of Medicinal Chemistry 201861 543-575. (https://doi. org/10.1021/acs.jmedchem.7b00168)

39 Nightingale G \& Ryu J. Cabazitaxel (jevtana): a novel agent for metastatic castration-resistant prostate cancer. Pharmacy and Therapeutics 201237 440-448.

40 de Bono JS, Oudard S, Ozguroglu M, Hansen S, Machiels JP, Kocak I, Gravis G, Bodrogi I, Mackenzie MJ, Shen L, et al. Prednisone plus cabazitaxel or mitoxantrone for metastatic castration-resistant prostate cancer progressing after docetaxel treatment: a randomised open-label trial. Lancet 2010376 1147-1154. (https://doi. org/10.1016/S0140-6736(10)61389-X)

41 Darshan MS, Loftus MS, Thadani-Mulero M, Levy BP, Escuin D, Zhou XK, Gjyrezi A, Chanel-Vos C, Shen R, Tagawa ST, et al. Taxaneinduced blockade to nuclear accumulation of the androgen receptor predicts clinical responses in metastatic prostate cancer. Cancer Research 201171 6019-6029. (https://doi.org/10.1158/0008-5472. CAN-11-1417)

42 Tsao CK, Cutting E, Martin J \& Oh WK. The role of cabazitaxel in the treatment of metastatic castration-resistant prostate cancer Therapeutic Advances in Urology 20146 97-104. (https://doi. org/10.1177/1756287214528557)

43 Sims RB. Sipuleucel-T: autologous cellular immunotherapy for men with asymptomatic or minimally symptomatic metastatic castrate resistant prostate cancer. Journal of Cancer 20112 357-359. (https:// doi.org/10.7150/jca.2.357)

44 Van Hook KV, Huang T \& Alumkal JJ. Orteronel for the treatment of prostate cancer. Future Oncology 201410 803-811. (https://doi. org/10.2217/fon.14.35)

45 Chow H, Ghosh PM, deVere White R, Evans CP, Dall'Era MA, Yap SA, Li Y, Beckett LA, Lara PN Jr \& Pan CX. A phase 2 clinical trial of everolimus plus bicalutamide for castration-resistant prostate cancer. Cancer 2016122 1897-1904. (https://doi.org/10.1002/cncr.29927)

46 Jurmeister S, Ramos-Montoya A, Sandi C, Pertega-Gomes N, Wadhwa K, Lamb AD, Dunning MJ, Attig J, Carroll JS, Fryer LG, et al. Identification of potential therapeutic targets in prostate cancer through a cross-species approach. EMBO Molecular Medicine 201810. (https://doi.org/10.15252/emmm.201708274)

47 Mohanty SK, Yagiz K, Pradhan D, Luthringer DJ, Amin MB, Alkan S \& Cinar B. STAT3 and STAT5A are potential therapeutic targets in castration-resistant prostate cancer. Oncotarget 20178 85997-86010. (https://doi.org/10.18632/oncotarget.20844)

48 Karnati HK, Panigrahi MK, Li Y, Tweedie D \& Greig NH. Adiponectin as a potential therapeutic target for prostate cancer. Current Pharmaceutical Design 201723 4170-4179. (https://doi.org/10.2174/1 381612823666170208123553)

49 Ferlay J, Soerjomataram I, Ervik M, Dikshit R, Eser S, Mathers C, Rebelo M, Parkin DM, Forman D \& Bray F. GLOBOCAN 2012 v1.2, Cancer Incidence and Mortality Worldwide: IARC CancerBase No. 11. Lyon, France: International Agency for Research on Cancer, 2015.

50 Goldhirsch A, Winer EP, Coates AS, Gelber RD, Piccart-Gebhart M, Thurlimann B, Senn HJ \& Panel members Personalizing the treatment of women with early breast cancer: highlights of the St
Gallen International Expert Consensus on the Primary Therapy of Early Breast Cancer 2013. Annals of Oncology 201324 2206-2223. (https://doi.org/10.1093/annonc/mdt303)

51 Jordan VC. Tamoxifen: a most unlikely pioneering medicine. Nature Reviews Drug Discovery 20032 205-213. (https://doi.org/10.1038/ nrd1031)

52 Vogel CL, Johnston MA, Capers C \& Braccia D. Toremifene for breast cancer: a review of 20 years of data. Clinical Breast Cancer 201414 1-9. (https://doi.org/10.1016/j.clbc.2013.10.014)

53 Martinkovich S, Shah D, Planey SL \& Arnott JA. Selective estrogen receptor modulators: tissue specificity and clinical utility. Clinical Interventions in Aging 20149 1437-1452. (https://doi.org/10.2147/ CIA.S66690)

54 Cole MP, Jones CT \& Todd ID. A new anti-oestrogenic agent in late breast cancer. An early clinical appraisal of ICI46474. British Journal of Cancer 197125 270-275. (https://doi.org/10.1038/bjc.1971.33)

55 Lerner HJ, Band PR, Israel L \& Leung BS. Phase II study of tamoxifen: report of 74 patients with stage IV breast cancer. Cancer Treatment Reports $1976601431-1435$.

56 Viladiu P, Bosch FX, Benito E \& Alonso MC. Antiestrogen tamoxifen in the treatment of advanced breast cancer: a series of 31 patients. Cancer Treatment Reports 197761 899-900.

57 Davies C, Pan H, Godwin J, Gray R, Arriagada R, Raina V, Abraham M, Medeiros Alencar VH, Badran A, Bonfill X, et al. Longterm effects of continuing adjuvant tamoxifen to 10 years versus stopping at 5 years after diagnosis of oestrogen receptor-positive breast cancer: Atlas, a randomised trial. Lancet $2013 \mathbf{3 8 1} 805-816$. (https://doi.org/10.1016/S0140-6736(12)61963-1)

58 Jordan VC \& Allen KE. Evaluation of the antitumour activity of the non-steroidal antioestrogen monohydroxytamoxifen in the DMBA-induced rat mammary carcinoma model. European Journal of Cancer 198016 239-251. (https://doi.org/10.1016/00142964(80)90156-5)

59 Shagufta \& Ahmad I. Tamoxifen a pioneering drug: an update on the therapeutic potential of tamoxifen derivatives. European Journal of Medicinal Chemistry 2018143 515-531. (https://doi.org/10.1016/j. ejmech.2017.11.056)

60 Vogel VG, Costantino JP, Wickerham DL, Cronin WM, Cecchini RS, Atkins JN, Bevers TB, Fehrenbacher L, Pajon ER Jr, Wade JL 3rd, et al. Effects of tamoxifen vs raloxifene on the risk of developing invasive breast cancer and other disease outcomes: the NSABP Study of tamoxifen and raloxifene (STAR) P-2 trial. JAMA 2006295 2727-2741. (https://doi.org/10.1001/jama.295.23.joc60074)

61 Carlson RW. The history and mechanism of action of fulvestrant. Clinical Breast Cancer 20056 (Supplement 1) S5-S8. (https://doi. org/10.3816/CBC.2005.s.008)

62 DeFriend DJ, Howell A, Nicholson RI, Anderson E, Dowsett M, Mansel RE, Blamey RW, Bundred NJ, Robertson JF \& Saunders C. Investigation of a new pure antiestrogen (ICI 182780) in women with primary breast cancer. Cancer Research $1994 \mathbf{5 4} 408-414$.

63 Howell A, DeFriend DJ, Robertson JF, Blamey RW, Anderson L, Anderson E, Sutcliffe FA \& Walton P. Pharmacokinetics, pharmacological and anti-tumour effects of the specific antioestrogen ICI 182780 in women with advanced breast cancer. British Journal of Cancer 199674 300-308. (https://doi.org/10.1038/ bjc.1996.357)

64 Dowsett M, Johnston SR, Iveson TJ \& Smith IE. Response to specific anti-oestrogen (ICI182780) in tamoxifen-resistant breast cancer. Lancet 1995345 525. (https://doi.org/10.1016/S01406736(95)90624-X)

65 Geisler J. Differences between the non-steroidal aromatase inhibitors anastrozole and letrozole - of clinical importance? British Journal of Cancer 2011104 1059-1066. (https://doi.org/10.1038/bjc.2011.58)

66 Cohen MH, Johnson JR, Li N, Chen G \& Pazdur R. Approval summary: letrozole in the treatment of postmenopausal women with advanced breast cancer. Clinical Cancer Research 20028 665-669.

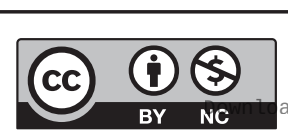

This work is licensed under a Creative Commons Attribution-NonCommercial 4.0 International License. ded from Bioscientifica.com at 04/26/2023 01:48:15PM 
67 Francis PA, Pagani O, Fleming GF, Walley BA, Colleoni M, Lang I, Gomez HL, Tondini C, Ciruelos E, Burstein HJ, et al. Tailoring adjuvant endocrine therapy for premenopausal breast cancer. New England Journal of Medicine 2018379 122-137. (https://doi. org/10.1056/NEJMoa1803164)

68 Regan MM, Francis PA, Pagani O, Fleming GF, Walley BA, Viale G, Colleoni M, Lang I, Gomez HL, Tondini C, et al. Absolute benefit of adjuvant endocrine therapies for premenopausal women With hormone receptor-positive, human epidermal growth factor Receptor 2-negative early breast cancer: TEXT and SOFT trials. Journal of Clinical Oncology 201634 2221-2231. (https://doi.org/10.1200/ JCO.2015.64.3171)

69 Howell A \& Buzdar A. Are aromatase inhibitors superior to antiestrogens? Journal of Steroid Biochemistry and Molecular Biology 200593 237-247. (https://doi.org/10.1016/j.jsbmb.2005.02.004)

70 Smith I, Yardley D, Burris H, De Boer R, Amadori D, McIntyre K, Ejlertsen B, Gnant M, Jonat W, Pritchard KI, et al. Comparative efficacy and safety of adjuvant letrozole Versus anastrozole in postmenopausal patients With hormone receptor-positive, nodepositive early breast cancer: final results of the randomized Phase III Femara Versus Anastrozole Clinical Evaluation (FACE) trial. Journal of Clinical Oncology 201735 1041-1048. (https://doi.org/10.1200/ JCO.2016.69.2871)

71 Hudis CA. Trastuzumab - mechanism of action and use in clinical practice. New England Journal of Medicine 2007357 39-51. (https:// doi.org/10.1056/NEJMra043186)

72 Tagliabue E, Campiglio M, Pupa SM, Menard S \& Balsari A. Activity and resistance of trastuzumab according to different clinical settings. Cancer Treatment Reviews 201238 212-217. (https://doi. org/10.1016/j.ctrv.2011.06.002)

73 Gerratana L, Bonotto M, Bozza C, Ongaro E, Fanotto V, Pelizzari G $\&$ Puglisi F. Pertuzumab and breast cancer: another piece in the antiHER2 puzzle. Expert Opinion on Biological Therapy 201717 365-374. (https://doi.org/10.1080/14712598.2017.1282944)

74 von Minckwitz G, Procter M, de Azambuja E, Zardavas D, Benyunes M, Viale G, Suter T, Arahmani A, Rouchet N, Clark E, et al. Adjuvant pertuzumab and trastuzumab in early HER2-positive breas cancer. New England Journal of Medicine 2017377 122-131. (https:// doi.org/10.1056/NEJMoa1703643)

75 Segovia-Mendoza M, Gonzalez-Gonzalez ME, Barrera D, Diaz L \& Garcia-Becerra R. Efficacy and mechanism of action of the tyrosine kinase inhibitors gefitinib, lapatinib and neratinib in the treatment of HER2-positive breast cancer: preclinical and clinical evidence. American Journal of Cancer Research 20155 2531-2561.

76 Larionov AA. Current therapies for human epidermal growth factor Receptor 2-positive metastatic breast cancer patients. Frontiers in Oncology 20188 89. (https://doi.org/10.3389/ fonc. 2018.00089)

77 Amiri-Kordestani L, Blumenthal GM, Xu QC, Zhang L, Tang SW, Ha L, Weinberg WC, Chi B, Candau-Chacon R, Hughes P, et al. FDA approval: ado-trastuzumab emtansine for the treatment of patients with HER2-positive metastatic breast cancer. Clinical Cancer Research 201420 4436-4441. (https://doi.org/10.1158/1078-0432.CCR-140012)

78 Dieras V, Miles D, Verma S, Pegram M, Welslau M, Baselga J, Krop IE, Blackwell K, Hoersch S, Xu J, et al. Trastuzumab emtansine versus capecitabine plus lapatinib in patients with previously treated HER2positive advanced breast cancer (EMILIA): a descriptive analysis of final overall survival results from a randomised, open-label, phase 3 trial. Lancet Oncology 201718 732-742. (https://doi.org/10.1016/ S1470-2045(17)30312-1)

79 Perez EA, Barrios C, Eiermann W, Toi M, Im YH, Conte P, Martin M, Pienkowski T, Pivot X, Burris H, 3rd, et al. Trastuzumab emtansine with or without pertuzumab versus trastuzumab plus taxane for human epidermal growth factor receptor 2-positive, advanced breast cancer: primary results from the phase III Marianne study. Journal of Clinical Oncology 201735 141-148. (https://doi.org/10.1200/ JCO.2016.67.4887)

80 Gnant M, Harbeck N \& Thomssen C. St. Gallen/Vienna 2017: a brief summary of the consensus discussion about escalation and de-escalation of primary breast cancer treatment. Breast Care $2017 \mathbf{1 2}$ 102-107. (https://doi.org/10.1159/000475698)

81 Lehmann BD, Bauer JA, Chen X, Sanders ME, Chakravarthy AB, Shyr Y \& Pietenpol JA. Identification of human triple-negative breast cancer subtypes and preclinical models for selection of targeted therapies. Journal of Clinical Investigation $20111212750-2767$. (https://doi.org/10.1172/JCI45014)

82 de Groot AF, Kuijpers CJ \& Kroep JR. CDK4/6 inhibition in early and metastatic breast cancer: a review. Cancer Treatment Reviews 201760 130-138. (https://doi.org/10.1016/j.ctrv.2017.09.003)

83 Cristofanilli M, Turner NC, Bondarenko I, Ro J, Im SA, Masuda N, Colleoni M, DeMichele A, Loi S, Verma S, et al. Fulvestrant plus palbociclib versus fulvestrant plus placebo for treatment of hormonereceptor-positive, HER2-negative metastatic breast cancer that progressed on previous endocrine therapy (PALOMA-3): final analysis of the multicentre, double-blind, phase 3 randomised controlled trial. Lancet Oncology 201617 425-439. (https://doi.org/10.1016/ S1470-2045(15)00613-0)

84 Finn RS, Crown JP, Ettl J, Schmidt M, Bondarenko IM, Lang I, Pinter T, Boer K, Patel R, Randolph S, et al. Efficacy and safety of palbociclib in combination with letrozole as first-line treatment of ER-positive, HER2-negative, advanced breast cancer: expanded analyses of subgroups from the randomized pivotal trial PALOMA-1/ TRIO-18. Breast Cancer Research 201618 67. (https://doi.org/10.1186/ s13058-016-0721-5)

85 Finn RS, Martin M, Rugo HS, Jones S, Im SA, Gelmon K, Harbeck N, Lipatov ON, Walshe JM, Moulder S, et al. Palbociclib and letrozole in advanced breast cancer. New England Journal of Medicine 2016375 1925-1936. (https://doi.org/10.1056/NEJMoa1607303)

86 Hortobagyi GN, Stemmer SM, Burris HA, Yap YS, Sonke GS, PaluchShimon S, Campone M, Petrakova K, Blackwell KL, Winer EP, et al. Updated results from MONALEESA-2, a phase III trial of first-line ribociclib plus letrozole versus placebo plus letrozole in hormone receptor-positive, HER2-negative advanced breast cancer. Annals of Oncology 201829 1541-1547. (https://doi.org/10.1093/annonc/ mdy155)

87 Tripathy D, Im SA, Colleoni M, Franke F, Bardia A, Harbeck N, Hurvitz SA, Chow L, Sohn J, Lee KS, et al. Ribociclib plus endocrine therapy for premenopausal women with hormone-receptor-positive, advanced breast cancer (MONALEESA-7): a randomised phase 3 trial. Lancet Oncology 201819 904-915. (https://doi.org/10.1016/S14702045(18)30292-4)

88 Goetz MP, Toi M, Campone M, Sohn J, Paluch-Shimon S, Huober J, Park IH, Tredan O, Chen SC, Manso L, et al. MONARCH 3: abemaciclib as initial therapy for advanced breast cancer. Journal of Clinical Oncology 201735 3638-3646. (https://doi.org/10.1200/ JCO.2017.75.6155)

89 Sledge GW Jr, Toi M, Neven P, Sohn J, Inoue K, Pivot X, Burdaeva O, Okera M, Masuda N, Kaufman PA, et al. MONARCH 2: Abemaciclib in combination With fulvestrant in women With HR+/HER2advanced breast cancer who had progressed while receiving endocrine therapy. Journal of Clinical Oncology 201735 2875-2884. (https://doi.org/10.1200/JCO.2017.73.7585)

90 Cancer Genome Atlas Network. Comprehensive molecular portraits of human breast tumours. Nature 2012490 61-70. (https://doi. org/10.1038/nature11412)

91 Piccart M, Hortobagyi GN, Campone M, Pritchard KI, Lebrun F, Ito Y, Noguchi S, Perez A, Rugo HS, Deleu I, et al. Everolimus plus exemestane for hormone-receptor-positive, human epidermal growth factor receptor-2-negative advanced breast cancer: overall survival results from BOLERO-2. Annals of Oncology 201425 2357-2362. (https://doi.org/10.1093/annonc/mdu456) https://ec.bioscientifica.com https://doi.org/10.1530/EC-18-0425 (c) 2019 The authors Published by Bioscientifica Ltd
This work is licensed under a Creative Commons Attribution-NonCommercial 4.0 International License. ed from Bioscientifica com at 04/26/2023 01:48:15PM 
92 Jhan JR \& Andrechek ER. Triple-negative breast cancer and the potential for targeted therapy. Pharmacogenomics 201718 1595-1609. (https://doi.org/10.2217/pgs-2017-0117)

93 Ashworth A. A synthetic lethal therapeutic approach: poly(ADP) ribose polymerase inhibitors for the treatment of cancers deficient in DNA double-strand break repair. Journal of Clinical Oncology 200826 3785-3790. (https://doi.org/10.1200/JCO.2008.16.0812)

94 Scott CL, Swisher EM \& Kaufmann SH. Poly (ADP-ribose) polymerase inhibitors: recent advances and future development. Journal of Clinical Oncology 201533 1397-1406. (https://doi.org/10.1200/ JCO.2014.58.8848)

95 Zimmer AS, Gillard M, Lipkowitz S \& Lee JM. Update on PARP inhibitors in breast cancer. Current Treatment Options in Oncology 2018 19 21. (https://doi.org/10.1007/s11864-018-0540-2)

96 Robson M, Im SA, Senkus E, Xu B, Domchek SM, Masuda N, Delaloge S, Li W, Tung N, Armstrong A, et al. Olaparib for metastatic breast cancer in patients with a germline BRCA mutation. New England Journal of Medicine 2017377 523-533. (https://doi. org/10.1056/NEJMoa1706450)

97 Amemiya S, Sekizawa A, Otsuka J, Tachikawa T, Saito H \& Okai T Malignant transformation of endometriosis and genetic alterations of K-ras and microsatellite instability. International Journal of Gynaecology and Obstetrics 200486 371-376. (https://doi.org/10.1016/j. ijgo.2004.04.036)

98 Winter WE, 3rd, Maxwell GL, Tian C, Carlson JW, Ozols RF, Rose PG, Markman M, Armstrong DK, Muggia F, McGuire WP, et al. Prognostic factors for stage III epithelial ovarian cancer: a Gynecologic Oncology Group Study. Journal of Clinical Oncology 200725 3621-3627. (https://doi.org/10.1200/JCO.2006.10.2517)

99 Testa U, Petrucci E, Pasquini L, Castelli G \& Pelosi E. Ovarian cancers: genetic abnormalities, tumor heterogeneity and progression, clonal evolution and cancer stem cells. Medicines 2018 5. (https://doi. org/10.3390/medicines5010016)

100 Berek JS \& Hacker NF. Berek and Hacker's Gynecologic Oncology, 6th ed. Philadelphia, PA, USA: Wolters Kluwer, 2015.

101 Lacey JV \& Sherman ME. Ovarian Neoplasia, 2nd ed. Oxford, UK: Churchill Livingstone Elsevier, 2009.

102 Köbel M, Kalloger SE, Huntsman DG, Santos JL, Swenerton KD Seidman JD \& Gilks CB. Differences in tumor type in low-stage versus high-stage ovarian carcinomas. International Journal of Gynecological Pathology 201029 203-211. (https://doi.org/10.1097/ PGP.0b013e3181c042b6)

103 Vang R, Shih IeM \& Kurman RJ. Ovarian low-grade and highgrade serous carcinoma: pathogenesis, clinicopathologic and molecular biologic features, and diagnostic problems. Advances in Anatomic Pathology 200916 267-282. (https://doi.org/10.1097/ PAP.0b013e3181b4fffa)

104 Chi DS, Musa F, Dao F, Zivanovic O, Sonoda Y, Leitao MM, Levine DA, Gardner GJ, Abu-Rustum NR \& Barakat RR. An analysis of patients with bulky advanced stage ovarian, tubal, and peritoneal carcinoma treated with primary debulking surgery (PDS) during an identical time period as the randomized EORTC-NCIC trial of PDS vs neoadjuvant chemotherapy (NACT). Gynecologic Oncology 2012124 10-14. (https://doi.org/10.1016/j.ygyno.2011.08.014)

105 Vergote I, Trope CG, Amant F, Kristensen GB, Ehlen T, Johnson N, Verheijen RH, van der Burg ME, Lacave AJ, Panici PB, et al. Neoadjuvant chemotherapy or primary surgery in stage IIIC or IV ovarian cancer. New England Journal of Medicine 2010363 943-953. (https://doi.org/10.1056/NEJMoa0908806)

106 Kehoe S, Hook J, Nankivell M, Jayson GC, Kitchener H, Lopes T, Luesley D, Perren T, Bannoo S, Mascarenhas M, et al. Primary chemotherapy versus primary surgery for newly diagnosed advanced ovarian cancer (CHORUS): an open-label, randomised, controlled, non-inferiority trial. Lancet 2015386 249-257. (https://doi. org/10.1016/S0140-6736(14)62223-6)
107 van Driel WJ, Koole SN, Sikorska K, Schagen van Leeuwen JH, Schreuder HWR, Hermans RHM, de Hingh IHJT, van der Velden J, Arts HJ, Massuger LFAG, et al. Hyperthermic intraperitoneal chemotherapy in ovarian cancer. New England Journal of Medicine 2018378 230-240. (https://doi.org/10.1056/NEJMoa1708618)

108 Spriggs DR \& Zivanovic O. Ovarian cancer treatment - are we getting warmer? New England Journal of Medicine 2018378 293-294. (https:// doi.org/10.1056/NEJMe1714556)

109 Alberts ME. Strive for better education. Iowa Medicine 199282479

110 Young RC, Walton LA, Ellenberg SS, Homesley HD, Wilbanks GD, Decker DG, Miller A, Park R \& Major F Jr. Adjuvant therapy in stage I and stage II epithelial ovarian cancer. Results of two prospective randomized trials. New England Journal of Medicine 1990322 1021-1027. (https://doi.org/10.1056/NEJM199004123221501)

111 McGuire WP, Hoskins WJ, Brady MF, Kucera PR, Partridge EE, Look KY, Clarke-Pearson DL \& Davidson M. Cyclophosphamide and cisplatin compared with paclitaxel and cisplatin in patients with stage III and stage IV ovarian cancer. New England Journal of Medicine 1996334 1-6. (https://doi.org/10.1056/NEJM199601043340101)

112 Ozols RF, Bundy BN, Greer BE, Fowler JM, Clarke-Pearson D, Burger RA, Mannel RS, DeGeest K, Hartenbach EM, Baergen R, et al. Phase III trial of carboplatin and paclitaxel compared with cisplatin and paclitaxel in patients with optimally resected stage III ovarian cancer: a Gynecologic Oncology Group study. Journal of Clinical Oncology 200321 3194-3200. (https://doi.org/10.1200/ JCO.2003.02.153)

113 Coluccia M \& Natile G. Trans-platinum complexes in cancer therapy. Anti-Cancer Agents in Medicinal Chemistry 20077 111-123. (https:// doi.org/10.2174/187152007779314080)

114 Burger RA, Brady MF, Bookman MA, Fleming GF, Monk BJ, Huang H, Mannel RS, Homesley HD, Fowler J, Greer BE, et al. Incorporation of bevacizumab in the primary treatment of ovarian cancer. New England Journal of Medicine 2011365 2473-2483. (https://doi. org/10.1056/NEJMoa1104390)

115 Oza AM, Cook AD, Pfisterer J, Embleton A, Ledermann JA, PujadeLauraine E, Kristensen G, Carey MS, Beale P, Cervantes A, et al. Standard chemotherapy with or without bevacizumab for women with newly diagnosed ovarian cancer (ICON7): overall survival results of a phase 3 randomised trial. Lancet Oncology 201516 928-936. (https://doi.org/10.1016/S1470-2045(15)00086-8)

116 Katsumata N, Yasuda M, Isonishi S, Takahashi F, Michimae H, Kimura E, Aoki D, Jobo T, Kodama S, Terauchi F, et al. Long-term results of dose-dense paclitaxel and carboplatin versus conventional paclitaxel and carboplatin for treatment of advanced epithelial ovarian, fallopian tube, or primary peritoneal cancer (JGOG 3016): a randomised, controlled, open-label trial. Lancet Oncology 201314 1020-1026. (https://doi.org/10.1016/S1470-2045(13)70363-2)

117 du Bois A, Floquet A, Kim JW, Rau J, del Campo JM, Friedlander M, Pignata S, Fujiwara K, Vergote I, Colombo N, et al. Incorporation of pazopanib in maintenance therapy of ovarian cancer. Journal of Clinical Oncology 201432 3374-3382. (https://doi.org/10.1200/ JCO.2014.55.7348)

118 du Bois A, Kristensen G, Ray-Coquard I, Reuss A, Pignata S, Colombo N, Denison U, Vergote I, Del Campo JM, Ottevanger P, et al. Standard first-line chemotherapy with or without nintedanib for advanced ovarian cancer (AGO-OVAR 12): a randomised, doubleblind, placebo-controlled phase 3 trial. Lancet Oncology 201617 78-89. (https://doi.org/10.1016/S1470-2045(15)00366-6)

119 Cortez AJ, Tudrej P, Kujawa KA \& Lisowska KM. Advances in ovarian cancer therapy. Cancer Chemotherapy and Pharmacology $2018 \mathbf{8 1}$ 17-38. (https://doi.org/10.1007/s00280-017-3501-8)

120 Siddiqui MK, Tyczynski J, Pahwa A \& Fernandes AW. Objective response rate is a possible surrogate endpoint for survival in patients with advanced, recurrent ovarian cancer. Gynecologic Oncology 2017 146 44-51. (https://doi.org/10.1016/j.ygyno.2017.03.515) https://ec.bioscientifica.com https://doi.org/10.1530/EC-18-0425 (c) 2019 The authors Published by Bioscientifica Ltd

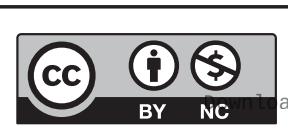

This work is licensed under a Creative Commons Attribution-NonCommercial 4.0 International License. ded from Bioscientifica.com at 04/26/2023 01:48:15PM 
121 Swisher EM, Lin KK, Oza AM, Scott CL, Giordano H, Sun J, Konecny GE, Coleman RL, Tinker AV, O'Malley DM, et al. Rucaparib in relapsed, platinum-sensitive high-grade ovarian carcinoma (ARIEL2 Part 1): an international, multicentre, open-label, phase 2 trial. Lancet Oncology 201718 75-87. (https://doi.org/10.1016/S14702045(16)30559-9)

122 Faraoni I \& Graziani G. Role of BRCA mutations in cancer treatment with poly(ADP-ribose) polymerase (PARP) inhibitors. Cancers 2018 10. (https://doi.org/10.3390/cancers10120487)

123 Oronsky B, Ray CM, Spira AI, Trepel JB, Carter CA \& Cottrill HM. A brief review of the management of platinum-resistant-platinumrefractory ovarian cancer. Medical Oncology 201734 103. (https://doi. org/10.1007/s12032-017-0960-z)

124 Pujade-Lauraine E, Hilpert F, Weber B, Reuss A, Poveda A, Kristensen G, Sorio R, Vergote I, Witteveen P, Bamias A, et al. Bevacizumab combined with chemotherapy for platinum-resistant recurrent ovarian cancer: the Aurelia open-label randomized phase III trial. Journal of Clinical Oncology 201432 1302-1308. (https://doi. org/10.1200/JCO.2013.51.4489)

125 Ercit K \& Gwynne DT. A novel method of comparing mating success and survival reveals similar sexual and viability selection for mobility traits in female tree crickets. Journal of Evolutionary Biology 201629 1189-1200. (https://doi.org/10.1111/jeb.12860)

126 Lindemann K, Gibbs E, Avall-Lundqvist E, dePont Christensen R, Woie K, Kalling M, Auranen A, Grenman S, Hoegberg T, Rosenberg P, et al. Chemotherapy vs tamoxifen in platinum-resistant ovarian cancer: a phase III, randomised, multicentre trial (Ovaresist). British Journal of Cancer 2017116 455-463. (https://doi.org/10.1038/bjc.2016.435)

127 Smyth JF, Gourley C, Walker G, MacKean MJ, Stevenson A, Williams AR, Nafussi AA, Rye T, Rye R, Stewart M, et al. Antiestrogen therapy is active in selected ovarian cancer cases: the use of letrozole in estrogen receptor-positive patients. Clinical Cancer Research 2007 13 3617-3622. (https://doi.org/10.1158/1078-0432.CCR-06-2878)

128 Argenta PA, Thomas SG, Judson PL, Downs LS Jr, Geller MA, Carson LF, Jonson AL \& Ghebre R. A phase II study of fulvestrant in the treatment of multiply-recurrent epithelial ovarian cancer. Gynecologic Oncology 2009113 205-209. (https://doi.org/10.1016/j. ygyno.2009.01.012)

129 Marth C, Vergote I, Scambia G, Oberaigner W, Clamp A, Berger R, Kurzeder C, Colombo N, Vuylsteke P, Lorusso D, et al. ENGOT-ov-6/ TRINOVA-2: randomised, double-blind, phase 3 study of pegylated liposomal doxorubicin plus trebananib or placebo in women with recurrent partially platinum-sensitive or resistant ovarian cancer. European Journal of Cancer $2017 \mathbf{7 0}$ 111-121. (https://doi. org/10.1016/j.ejca.2016.09.004)

130 Monk BJ, Poveda A, Vergote I, Raspagliesi F, Fujiwara K, Bae DS, Oaknin A, Ray-Coquard I, Provencher DM, Karlan BY, et al. Final results of a phase 3 study of trebananib plus weekly paclitaxel in recurrent ovarian cancer (TRINOVA-1): long-term survival, impact of ascites, and progression-free survival-2. Gynecologic Oncology 2016 143 27-34. (https://doi.org/10.1016/j.ygyno.2016.07.112)

131 Mabuchi S, Kuroda H, Takahashi R \& Sasano T. The PI3K/ AKT/mTOR pathway as a therapeutic target in ovarian cancer. Gynecologic Oncology 2015137 173-179. (https://doi.org/10.1016/j. ygyno.2015.02.003)

132 Farley J, Brady WE, Vathipadiekal V, Lankes HA, Coleman R, Morgan MA, Mannel R, Yamada SD, Mutch D, Rodgers WH, et al.
Selumetinib in women with recurrent low-grade serous carcinoma of the ovary or peritoneum: an open-label, single-arm, phase 2 study. Lancet Oncology 201314 134-140. (https://doi.org/10.1016/S14702045(12)70572-7)

133 Moore KN, Martin LP, O’Malley DM, Matulonis UA, Konner JA, Perez RP, Bauer TM, Ruiz-Soto R \& Birrer MJ. Safety and activity of mirvetuximab soravtansine (IMGN853), a folate receptor alphatargeting antibody-drug conjugate, in platinum-resistant ovarian, fallopian tube, or primary peritoneal cancer: a phase I expansion study. Journal of Clinical Oncology 201735 1112-1118. (https://doi. org/10.1200/JCO.2016.69.9538)

134 Bookman MA, Darcy KM, Clarke-Pearson D, Boothby RA \& Horowitz IR. Evaluation of monoclonal humanized anti-HER2 antibody, trastuzumab, in patients with recurrent or refractory ovarian or primary peritoneal carcinoma with overexpression of HER2: a phase II trial of the Gynecologic Oncology Group. Journal of Clinical Oncology 200321 283-290. (https://doi.org/10.1200/ JCO.2003.10.104)

135 Pakish JB \& Jazaeri AA. Immunotherapy in gynecologic cancers: are we there yet? Current Treatment Options in Oncology 20171859. (https://doi.org/10.1007/s11864-017-0504-y)

136 Gucalp A \& Traina TA. Targeting the androgen receptor in triplenegative breast cancer. Current Problems in Cancer 201640 141-150. (https://doi.org/10.1016/j.currproblcancer.2016.09.004)

137 Kono M, Fujii T, Lim B, Karuturi MS, Tripathy D \& Ueno NT. Androgen receptor function and androgen receptor-targeted therapies in breast cancer: a review. JAMA Oncology 20173 1266-1273. (https://doi.org/10.1001/jamaoncol.2016.4975)

138 Gucalp A, Tolaney S, Isakoff SJ, Ingle JN, Liu MC, Carey LA, Blackwell K, Rugo H, Nabell L, Forero A, et al. Phase II trial of bicalutamide in patients with androgen receptor-positive, estrogen receptor-negative metastatic Breast Cancer. Clinical Cancer Research 201319 5505-5512. (https://doi.org/10.1158/1078-0432.CCR-123327)

139 Bonnefoi H, Grellety T, Tredan O, Saghatchian M, Dalenc F, Mailliez A, L'Haridon T, Cottu P, Abadie-Lacourtoisie S, You B, et al. A phase II trial of abiraterone acetate plus prednisone in patients with triple-negative androgen receptor positive locally advanced or metastatic breast cancer (UCBG 12-1). Annals of Oncology 201627 812-818. (https://doi.org/10.1093/annonc/mdw067)

140 Shiba E, Yamashita H, Kurebayashi J, Noguchi S, Iwase H, Ohashi Y, Sasai K \& Fujimoto T. A randomized controlled study evaluating safety and efficacy of leuprorelin acetate every-3-months depot for 2 versus 3 or more years with tamoxifen for 5 years as adjuvant treatment in premenopausal patients with endocrine-responsive breast cancer. Breast Cancer 201623 499-509. (https://doi. org/10.1007/s12282-015-0593-z)

141 Mateo J, Carreira S, Sandhu S, Miranda S, Mossop H, Perez-Lopez R, Nava Rodrigues D, Robinson D, Omlin A, Tunariu N, et al. DNArepair defects and olaparib in metastatic prostate cancer. New England Journal of Medicine 2015373 1697-1708. (https://doi.org/10.1056/ NEJMoa1506859)

142 Stice JP, Wardell SE, Norris JD, Yllanes AP, Alley HM, Haney VO, White HS, Safi R, Winter PS, Cocce KJ, et al. CDK4/6 therapeutic intervention and viable alternative to taxanes in CRPC. Molecular Cancer Research 201715 660-669. (https://doi.org/10.1158/15417786.MCR-17-0028)

Received in final form 13 December 2018

Accepted 14 January 2019

Accepted Preprint published online 14 January 2019 https://ec.bioscientifica.com https://doi.org/10.1530/EC-18-0425 (c) 2019 The authors Published by Bioscientifica Ltd

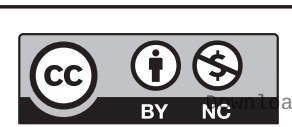

This work is licensed under a Creative Commons Attribution-NonCommercial 4.0 International License. ded from Bioscientifica com at 04/26/2023 01:48:15PM 